DOI: 10.52363/passa-2021.1-7

UDC: 351.355:327.56

Grybko O., PhD in Public Administration, Associate professor of Department of Pedagogy and Psychology of Social System Management named after academican I.A. Zyazun, National Technical University "KhPI", Kharkiv

\title{
COUNTERING HYBRID THREATS IN THE CONTEXT OF CHANGING GLOBAL ENVIRONMENT
}

Ensuring global security requires finding a collective response to global challenges - complex and dynamic in nature. Thus, the issues of ensuring the environment and public health, ensuring food safety, combating terrorism (including such in cyberspace), illegal migration and hybrid threats are particularly acute for the state and society.

Key words: hybrid threats; global security; European Union.

Formulation of the problem. In modern world, the global component is becoming dominant, and therefore nowadays potential threats directly or indirectly affect everyone in every corner of the world. Ensuring global security requires finding a collective response to global challenges - complex and dynamic in nature. Thus, the issues of ensuring the environment and public health, ensuring food safety, combating terrorism (including in such cyberspace), illegal migration and hybrid threats are particularly acute for the state and society.

The peculiarity of hybrid-type challenges is that they are disguised and used mostly nonlinear tactics and are aimed, for example, not at capturing the entire territory of the country, although it is possible to take control of individual territories, but to gain patronage over the state by influence on the population, political system, business, law enforcement authorities. Therefore, combating hybrid threats, which must be clearly identified in the state, requires attention to increase the resilience of society. Not only the 
state power authorities, but also practically all ministries and departments, nongovernmental organizations, business, civil society are involved in counteracting hybrid threats.

The purpose of our study is to determine the place of counteraction to hybrid threats as a component of global security complex and to suggest ways to intensify Ukraine's participation in the European system of counteraction and prevention of hybrid threats.

Analysis of recent research and publications has identified previously unresolved parts of the overall problem, namely: determining the place of hybrid threats in the complex of other global threats; analyze common European system for counteracting global threats and Ukraine's place in it.

Similar problems have been searched by such domestic and foreign scientists as E. Bajarūnas, F. Hoffman, J. Mattis, H. Vasiliiev.

Main body. Global international security can actually be described as a state in which the whole system of international relations and its main actors (sovereign countries and international organizations) adhere to generally accepted principles and norms of international law [1]. The desire for such a state, if not completely eliminates, at least significantly reduces the urge to resolve disputes and conflicts through force or threats.

However, quite often, geopolitical realities that determine the complex relationship between politics, geography and the system of international relations - force different nations to realize their own national interests at the expense of other states, sometimes violating these principles and norms of international law.

Thus, on one level with pandemics, man-made disasters and other global threats, a new basis for their formation and hybridization is emerging. Countries-sources of hybrid threats purposefully and massively use methods of hybrid war against their opponents, and violating the global structure of international cooperation.

F. Hoffman and J. Mattis describe the theory of fourth-generation war, compound (multi-part, mixed, complex), unlimited war (war without borders). We come to the conclusion, writes Hoffman, that in the future we will not face a number of opponents, each 
of whom chooses some singular, unconventional or different, method of confrontation, but with opponents who simultaneously combine all methods of confrontation, which manifest themselves in the form of multimodal (mixed) or hybrid wars [13].

When developing strategy for a hybrid war, the most important properties of hybrid threats are taken into account, ensuring their effective use at all stages of a hybrid war and giving threats much more destructive power than a simple sum of individual threats. The "cumulative effect" from the impact of this type threats is ensured by the implementation of system of complex and interdependent preparatory and executive measures related to the coordination of the significant number of participants activities operating on the territory of the target country and abroad. So we should take into account all complex of potential threats for analysis.

The model of hybrid threats analysis is presented in Figure 1.

\begin{tabular}{|c|}
\hline Fixation of certain elements of the system \\
\hline Display the relationship between system elements and with other systems \\
\hline Distribution of elements by their significance \\
\hline Display of dependencies and degrees of influence \\
\hline Definition of "crisis points" by types and levels \\
\hline Delineation of intersection areas of existing power centers interests \\
\hline
\end{tabular}

Figure 1. The model of hybrid threats analysis.

Next, an algorithm is connected, which reflects the sequence of assessing the situations that develop in the areas exposed to hybrid threats, determines the correspondence of situation development to the selected scenario, the development, coordination and implementation of decisions that ensure the achievement of goals and objectives take place. Its important function is continuous monitoring of the situation in the administrative-political, financial-economic, informational, cybernetic, military, cultural and ideological spheres and assessing the impact of decisions made under the situation. 
Coordinated application of coercive policies, subversive activities, traditional and non-traditional methods (id est diplomatic, military, economic, technological), without a formal declaration of war - are signs of threats hybridization to global security, even if all used at a local or regional level [2].

In fact, there is no single definition of hybrid threats today [7], but their systemic nature and the need to find ways to counteraction them - in particular at the global level, because they arise on it.

European integration is a purely regional unification process, but the current challenges to global security are particularly acute at this level. The EU is gradually changing, and its institutions are trying to find systematic and adequate responses to global challenges, including hybrid threats.

The search for a common European response to global security challenges began in the late 1990s, when the Saint-Malo Declaration was signed. This declaration referred to the EU's ability to act autonomously, including use of military force. However, special emphasis was placed on the Union's readiness to act in accordance with Articles 5 of the Washington and Brussels Treaties - guaranteeing its obligations to ensure collective defense. In this context, the EU has declared the need to align its innovations with those of NATO members.

The next important step in the search for common European response to global security challenges was the adoption of the EU Security Strategy in 2003 and the EU Global Strategy in 2016 [15]. In general, the 2003 strategy was a rather optimistic document in terms of the perception of the future of European integration. In particular, the text of document begins with the words: "Europe has never been so prosperous, so secure and so free." On the other hand, the EU Global Strategy 2016 begins somewhat less optimistically: "The purpose, even the existence of our Union is called into question" [8].

In fact, common European response to the challenges to global security in the new EU Global Strategy is expected to be sought in the "strategic autonomy" that echoes the ideas declared at the 1998 meeting in Saint-Malo. In addition, the new strategy 
conceptualizes the "resilience" of Europe, obviously primarily to the challenges of global security.

On June 23, 2017, the EU officially launched Permanent Structured Cooperation (PESCO), which focuses on projects to build new weapons, equipment, increase military capabilities and other commitments (including regular increases in defense budgets and increased spending on new ones) [14].

The EU is currently responding to global security challenges, by building its own institutional framework to counteraction hybrid threats.

Since 2017, within the EU Intelligence and Situation Center (EU INTCEN [9]) of the European External Action Service, there is an EU Hybrid Fusion Cell, which collects and analyzes information on hybrid threats. The Center issues a periodic report on current situation in this area to familiarize them with the institutions and EU member states [12].

The COVID-19 pandemic has forced the EU to intensify its common health policy (as part of a common social policy) and to give a helping hand to their neighbors. Without the need to counteraction this global threat, Member States would hardly dare to intensify integration in this direction in the foreseeable future, but the EU institutions have proved to be quite effective in developing common approaches to countering this threat.

The EU is also assisting developing countries in achieving the UN's 2030 Sustainable Development Goals. For example, in Ukraine, the thematic program of food safety is implemented in the direction of improving the food safety efficiency management at the continental, regional and national levels [3].

Thus, the issue of global security is not limited to countering hybrid threats. Global pandemics, global climate change, malnutrition and hunger, various man-made disasters, cyberterrorism and other problems common to all mankind remain equally relevant. The situation is also exacerbated by the interdependence of all mankind, which is intensifying in the context of globalization - while the events taking place in one part of the world almost equally affect the regions of another part of the world.

However, by and large, any modern global threat in one way or another is used for their own purposes by sources of hybrid threats. This can be both an informational, 
propaganda component and direct use (for example, in global economic downturn during a pandemic - a potential increase in economic pressure on a geopolitical adversary). Thus, it is impossible to completely single out any one threat to global security from the whole complex of negative effects multiplication, so that it would be considered and counteracted separately and independently of others, including hybrid threats.

Considering the current security issues in Ukraine in the context of global challenges, it should be noted that the main factor in this issue is that Ukraine is not a global player. Generally, sometimes engaging in international activities at the regional level, Ukraine does not become a leading actor in it. At the same time, Ukraine remains as vulnerable to global threats as other countries.

National Security Strategy of Ukraine [5] identifies a number of threats to national security, from which we can identify threats of a global character, which are likely to be similar for entire system of international cooperation. We are talking about: climate change and increasing man-made pressure on the environment; imbalance of world development and global governance instruments; development of weapons systems based on new physical principles; strengthening international competition with the use of all national strength instruments; the spread of international terrorism and international crime, in particular in cyberspace; financial and economic crisis; hybrid war, and aggressive actions of the Russian Federation in various geopolitical regions (also against Ukraine); high degree of uncertainty and unpredictability of the situation in the world as a whole [5].

Thus, Ukraine, not being a global player, but having national challenges equivalent to global ones, must attract help to overcome them. At most, this is expressed and is based on active involvement in integration processes in the European and Euro-Atlantic region.

For example, the creation by the European External Action Service of the StratcomEast expert group, which aims to support the Eastern Partnership's information security policy and counteraction Russia's ongoing disinformation campaigns, has allowed 
Ukraine to receive practical EU support in the field of information security.

Participation in regional associations, such as the Lublin Triangle [6], which is a new format of cooperation between Ukraine, Poland and Lithuania, including in the field of countering threats in different spheres, allows for conditional transposition regional impact in the global dimension.

For example, Lithuanian expert Eitvidas Bayarunas in 2020, who took an active part in the development of a joint triangle cybersecurity strategy, emphasizes that today the fight against hybrid threats in cyberspace is becoming extremely important [4]. It is important to mention that according to the global cybersecurity index, Lithuania ranks 6th among world countries, while Ukraine ranks 78th [11].

Accordingly, the main vector of Ukraine's security integration should be the intensification of participation in European counteraction and prevention system of global threats - both through the involvement of regional institutions in the system, and through regional political and security cooperation with allies. Thus, there is a necessity to concretize and unify the interaction between the union states and Ukraine at the level of legislation, with the consolidation of the peculiarities of such interaction and the term "ally of Ukraine".

Looking for an answer to Ukraine's place in ensuring both its own and global security, it is expedient to consider the answers to this question through a three-digit matrix: what Ukraine can do on its own to ensure national security; what Ukraine can do with foreign allied assistance to ensure national security; what Ukraine can do to ensure the security of its allies (as part of international regional or global security).

Conclusions. The above analysis of current EU practices in the field of global and regional security showed that the common European response to current challenges is to be found in "strategic autonomy" and "sustainability", in accordance with the EU Global Strategy. Thus, the EU member states have intensified the formation of common institutional structure for countering global and regional threats (including hybrid ones) - 
without abandoning the advantages of the Euro-Atlantic integration process in this aspect.

The place of counteraction to hybrid threats in the complex of global security is determined by the fact that this issue is not limited to the prevention of only this type of possible dangers. However, de facto any modern global threat in one way or another is used for their own purposes by the states-sources of hybrid threats.

Thus, Ukraine, not being a global player, but having national challenges equivalent to global ones, must attract assistance in overcoming them by intensifying participation in the system of European counteraction and prevention of hybrid threats. This requires strengthening the vector of security integration in terms of involvement in the institutional complex of ensuring common European security and defense policy, and concretization and unification of relations between the allied states and Ukraine at the legislative level.

\section{References}

1. Vasyliev H.Yu. pidtrymka mizhnarodnoi bezpeky - hlobalna problema liudstva. Visnyk Natsionalnoho universytetu «Yurydychna akademiia Ukrainy imeni Yaroslava Mudroho». № 2 (21). Kharkiv. 2014. URL: http://dspace.nlu.edu.ua/bitstream/123456789/8356/1/Vasiliev_155.pdf. [in Ukrainian].

2. Hibrydni zahrozy Ukraini i suspilna bezpeka. Dosvid YeS i skhidnoho partnerstva. Analitychnyi dokument. Hromadska Synerhiia. Kyiv, 2018. URL: https://www.civic-synergy.org.ua/wpcontent/uploads/2018/04/blok_XXI-end_0202.pdf. [in Ukrainian].

3. Grybko O.V. Harantuvannia prodovolchoi bezpeky yak odyn z priorytetnykh natsionalnykh interesiv. Aktualni problemy derzhavnoho upravlinnia. № 2(58). 2020. S. 62-69 URL: http://ap.kh.ua/index.php/apdu/issue/view/22. doi: 10.34213/ap.20.02.06 [in Ukrainian].

4. Lytovskyi ekspert po bezopasnosti: Rossyia - osnovnoj istochnik gibridnykh ugroz. URL : https://www.lrt.lt/ru/novosti/17/1062770/litovskii-ekspert-po-bezopasnosti-rossiia-osnovnoi-istochnikgibridnykh-ugroz [in Russian].

5. Pro rishennia Rady natsionalnoi bezpeky i oborony Ukrainy vid 14 veresnia 2020 roku «Pro Stratehiiu natsionalnoi bezpeky Ukrainy» : Ukaz Prezydenta Ukrainy № 392/2020. URL: https://www.president.gov.ua/documents/3922020-35037 [in Ukrainian]. 
6. Spilna deklaratsiia ministriv zakordonnykh sprav Ukrainy, Respubliky Polshcha ta Lytovskoi Respubliky shchodo zasnuvannia «Liublinskoho trykutnyka». Uriadovyi portal. 2020. URL: https://www.kmu.gov.ua/news/spilna-deklaraciya-ministriv-zakordonnih-sprav-ukrayini-respublikipolshcha-ta-litovskoyi-respubliki-shchodo-zasnuvannya-lyublinskogo-trikutnika [in Ukrainian].

7. A Europe that Protects: Countering Hybrid Threats. European External Action Service. 2018. URL : https://eeas.europa.eu/topics/economic-relations-connectivity-innovation/46393/europe-protectscountering-hybrid-threats_en [in English].

8. A Global Strategy for the European Union's Foreign And Security Policy «Shared Vision, Common Action: A Stronger Aurope». $2016 . \quad$ URL : http://eeas.europa.eu/archives/docs/top_stories/pdf/eugs_review_web.pdf. [in English].

9. European External Action Service HQ Organisation chart as of 16 July 2020. URL: https://eeas.europa.eu/sites/eeas/files/2020__16__07__eeas_2.0_orgchart.pdf. [in English].

10. Franco-British St. Malo Declaration (4 December 1998). Digital Research in European Studies. URL: $\quad$ https://www.cvce.eu/content/publication/2008/3/31/f3cd16fb-fc37-4d52-936fc8e9bc80f24f/publishable_en.pdf. [in English].

11. Global Cybersecurity Index 2020. URL: https://www.itu.int/myitu//media/Publications/2021-Publications/Global-Cybersecurity-Index-2020.pdf [in English].

12. Joint report to the European parliament and the Council on the implementation of the Joint Framework on countering hybrid threats - a European Union response. URL: https://ec.europa.eu/docsroom/documents/24601/attachments/1/translations/en/renditions/native. [in English].

13. Mattis J. N., Hoffman F. G. (2005). Future Warfare: The Rise of Hybrid Wars. US Naval Institute Proceedings Magazine. November. Vol. 132/11. P. 18-19. URL: http://milnewstbay.pbworks.com/f/MattisFourBlockWarUSNINov2005.pdf. [in English].

14. PESCO : Official website. URL : https://pesco.europa.eu. [in English].

15. The European Centre of Excellence for Countering Hybrid Threats (Hybrid CoE). URL : https://www.hybridcoe.fi. [in English]. 